\title{
CFD analysis on the aerodynamics characteristics of Jakarta-Bandung high speed train
}

\author{
Tony Utomo ${ }^{1, *}$, Berkah Fajar $^{1}$, and Hendry Arpriyanto ${ }^{2}$ \\ ${ }^{1}$ Mechanical Engineering Department, Faculty of Engineering, Diponegoro University, Indonesia \\ ${ }^{2}$ College of Mechanical Engineering Department, Diponegoro University, Indonesia
}

\begin{abstract}
In this study, the aerodynamics characteristics of HST type CRH380A which is planned to be operated on the new railway of JakartaBandung are analysed using Computational Fluid Dynamics. The speed of the train in this simulation was varied from $100 \mathrm{~km} / \mathrm{h}$ to a maximum designed speed of $350 \mathrm{~km} / \mathrm{h}$ with the increment of $30 \mathrm{~km} / \mathrm{h}$. The train was modelled in 3D computational domain with more than 1.7 million cells. The turbulence model employed in this study was standard $k-\omega$. The simulation results show that the drag coefficient $\left(C_{\mathrm{D}}\right)$ is slightly decrease by the increase of speed. At the speed of $100 \mathrm{~km} / \mathrm{h}$ the $C_{\mathrm{D}}$ is 0.216 and decrease to 0.188 at the speed of $350 \mathrm{~km} / \mathrm{h}$. The high pressure area is located at the nose of the train. The pressure acting on this location is increase with the increase of the train speed.
\end{abstract}

\section{Introduction}

The development of high speed train (HST) in the world is very rapid recently. The aerodynamics characteristic such as drag and lift forces become important in a high speed train, since the flows around train are more disturbed due to turbulence of the increased speed of the train $[1,2,3]$. These aerodynamic performances of a high speed train are strongly influence the energy consumption of the train.

The Indonesian government in cooperation with PT Kereta Api Cepat Indonesia China (PT KCIC) planned to build Jakarta-Bandung railroads special for a high speed train. The total distance is about $142.3 \mathrm{~km}$, starting from Jakarta Halim station up to the station Tegal Luar in Bandung regency. The distance between stations is about $45 \mathrm{~km}$. For this purpose, the consortium has decided to use a CRH380A high speed train. The CRH380A high speed train is able to reach a maximum operating speed of $350 \mathrm{~km} / \mathrm{h}$ after a distance of $39.01 \mathrm{~km}$ [4]. Such speed can possibly be reached on Jakarta-Bandung railroads. The aerodynamic phenomena with regard to high speed train are strongly dependent on the train speed. Thus, the aerodynamic problems become more important as the train speed increase.

In general, the aerodynamic problems are related to the aerodynamic characteristic of a high speed train, and the two of them are aerodynamic drag and lift. The aerodynamic drag and lift are dependent on the geometric parameter of the train, such as cross-sectional area

* Corresponding author: $\underline{\text { msktonysu@yahoo.co.id }}$ 
of train body, train length, shape of train fore- and after-bodies, etc [5]. Hence, the aerodynamics characteristics and flow phenomena around high speed train are necessary to understand. In this study, the influence of train speed on aerodynamics characteristics and flow phenomena around a high speed train are analyzed using computational fluid dynamics method.

\section{Computational Method}

In this study, the computational method is used to solve the three governing equations, which are mass conservation, momentum equation and $k-\omega$ standard turbulent model. The method consists of modeling high speed train geometry, generating mesh for computational domain, applying boundary conditions and initial conditions for simulation, and numerical iteration to solve the governing equations.

The train model was created using CAD software as shown in Figure 1. This model is a result of the simplification of the actual CRH380A geometry.

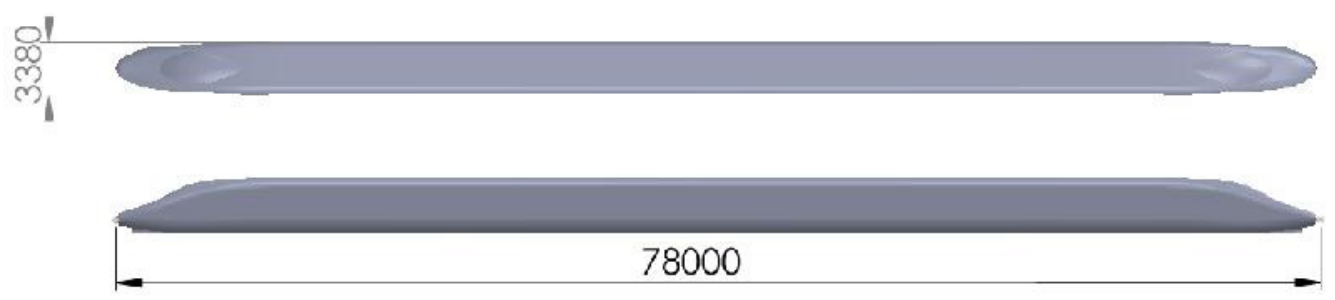

(a)

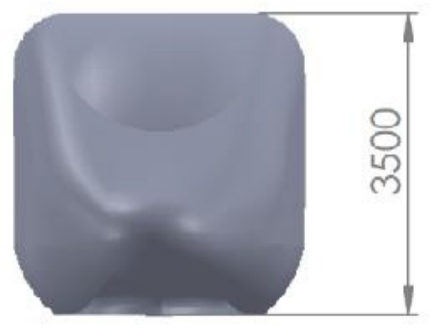

(b)

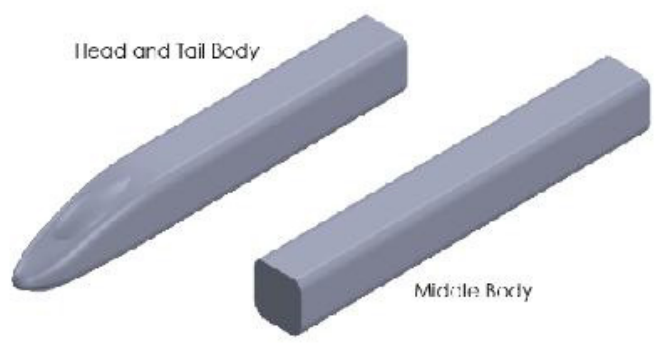

(c)

Fig. 1. Result of 3D model CRH380A (a) side and top view (b) front view(c) isometris view.

The computational domain of high speed train in this simulation is shown in Figure 2. In this figure, $\mathrm{L}$ is stand for the total length of the train. Inflow has a distance L upstream of the train nose, while the outflow has a distance $2 \mathrm{~L}$ from the back-end of the train. The width of the computational domain is set to $\mathrm{L}$, while it's height is set as $0,5 \mathrm{~L}$. The space between the base of the train to the ground is $0,00235 \mathrm{~L}$.

Mesh was divided into three main parts that had different dimension for each mesh. The first part was the surface of CRH380A with an element size of $100 \mathrm{~mm}$, the second part was car box with an element size of $375 \mathrm{~mm}$, while the last part was the outer covering of car box with default meshing size. The result of meshing can be seen in Figure 3 . The number element is 1.730 .605 cells with the maximum skewness of 0.74 (good quality mesh 


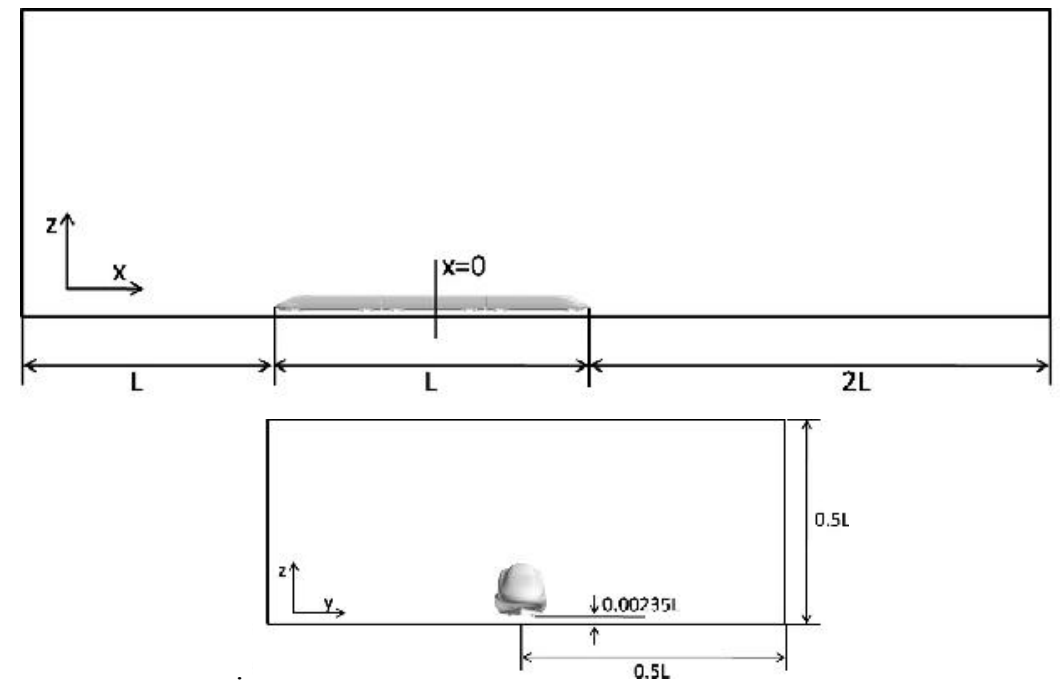

Fig.2. Computational domain

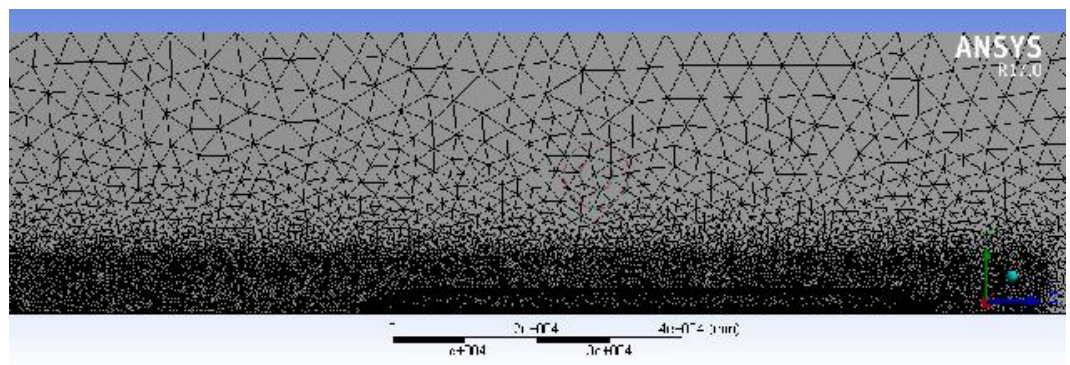

Fig. 3. Meshing of computational domain.

The boundary condition of computational domain is illustrated in Figure 4. The type of boundary condition of surface "a" is set as velocity inlet, surface " $b$ " is set as symmetry, surface "c" is no-slip stationary wall condition, surface " $d$ " is set as pressure outlet, surface "e" is stationary wall, and surface " $\mathrm{f}$ " is set as top wall and side wall with symmetry boundary condition type. The simulation was conducted by varying the speed from 100 $\mathrm{km} / \mathrm{h}$ up to $350 \mathrm{~km} / \mathrm{h}$ with increments of $30 \mathrm{~km} / \mathrm{h}$.

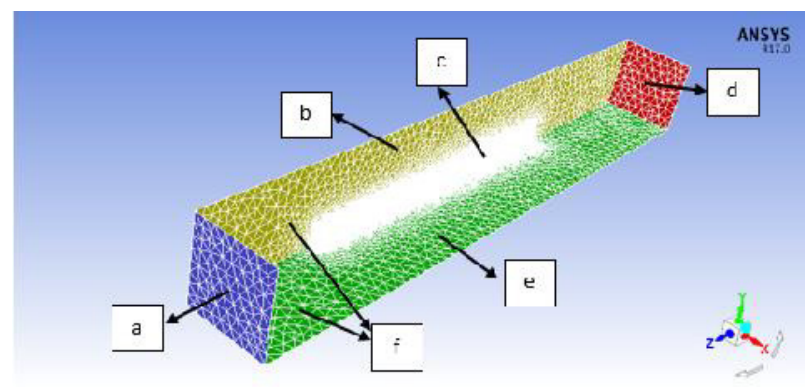

Figure 4. Boundary condition of computational domain. 


\section{Results and Discussion}

Table 1 shows the aerodynamic forces obtained from this simulation. The drag coefficient $\left(C_{\mathrm{D}}\right)$ is slightly decrease by the increase of speed. At the speed of $100 \mathrm{~km} / \mathrm{h}$ the $C_{\mathrm{D}}$ is 0.216 and decrease to 0.188 at the speed of $350 \mathrm{~km} / \mathrm{h}$.

Table 1. Drag and Lift of high speed train type CRH380A at various speed.

\begin{tabular}{|c|c|c|c|c|c|c|c|}
\hline No & $\begin{array}{c}\text { Velocity } \\
\mathrm{km} / \mathrm{h} \\
\mathrm{V}\end{array}$ & $\begin{array}{c}\text { Reynold } \\
\text { Number } \\
\mathrm{Re}\end{array}$ & $\begin{array}{c}\text { Drag } \\
\text { Coefficient } \\
C_{\mathrm{D}}\end{array}$ & $\begin{array}{c}\text { Pressure Drag } \\
\text { Coefficient } \\
C_{\text {D pressure }}\end{array}$ & $\begin{array}{c}\text { Viscous } \\
\text { Drag } \\
\text { Coefficient } \\
C_{\mathrm{D} \text { Viscous }}\end{array}$ & $\begin{array}{c}\text { DragForce } \\
\mathrm{kN} \\
F_{\mathrm{D}}\end{array}$ & $\begin{array}{c}\text { LiftForce } \\
\mathrm{kN}\end{array}$ \\
$F_{\mathrm{L}}$ \\
\hline 1 & 100 & $6.66 \times 10^{6}$ & 0.216 & 0.077 & 0.139 & 0.584 & -0.084 \\
\hline 2 & 130 & $8.65 \times 10^{6}$ & 0.210 & 0.075 & 0.135 & 0.958 & -0.162 \\
\hline 3 & 160 & $1.06 \times 10^{7}$ & 0.204 & 0.073 & 0.131 & 1.415 & -0.274 \\
\hline 4 & 190 & $1.26 \times 10^{7}$ & 0.201 & 0.072 & 0.129 & 1.956 & -0.418 \\
\hline 5 & 220 & $1.46 \times 10^{7}$ & 0.197 & 0.071 & 0.126 & 2.579 & -0.597 \\
\hline 6 & 250 & $1.66 \times 10^{7}$ & 0.194 & 0.070 & 0.124 & 3.283 & -0.809 \\
\hline 7 & 280 & $1.86 \times 10^{7}$ & 0.192 & 0.069 & 0.123 & 4.067 & -1.057 \\
\hline 8 & 310 & $2.06 \times 10^{7}$ & 0.190 & 0.069 & 0.121 & 4.930 & -1.341 \\
\hline 9 & 350 & $2.33 \times 10^{7}$ & 0.188 & 0.068 & 0.119 & 6.202 & -1.779 \\
\hline
\end{tabular}

It can be seen that the drag force is increasing proportionally to the increase of train speed. The maximum drag force $(6.202 \mathrm{kN})$ is obtained when the train traveling at it's maximum speed of $350 \mathrm{~km} / \mathrm{h}$. The lift force acting on the train is negative. This negative value means a down force. The maximum lift force acting at maximum train speed is -1.779 $\mathrm{kN}$.

Figure 5 shows the contour of static pressure around the HST body at the train speed of $100 \mathrm{~km} / \mathrm{h}, 190 \mathrm{~km} / \mathrm{h}, 220 \mathrm{~km} / \mathrm{h}$ and $350 \mathrm{~km} / \mathrm{h}$. It can be seen that the high pressure area is located at the nose of the train. The pressure acting on this location is increase with the increase of the train speed. At low speeds, the intensity of high pressure located around the nose train is not visible. At the higher train speed, the area of high pressure intensity becomes visible. When the train moves at it's maximum operating speed, the high pressure area is observable at front-end of the train nose and at the obstacle deflector located under the train nose. The maximum pressure on the nose and the obstacle deflector is $5.7 \mathrm{kPa}$. At maximum speed, the pressure drag is high and so is the drag force. An aerodynamically good design of a high speed train can reduce the pressure drag at the front of the train to reduce total drag force for efficient fuel consumption.

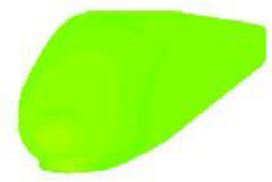

(a)

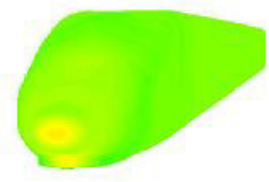

(b)

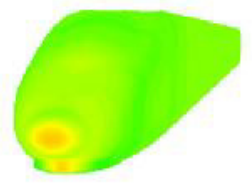

(c)

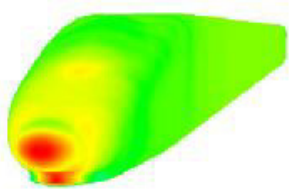

(d)

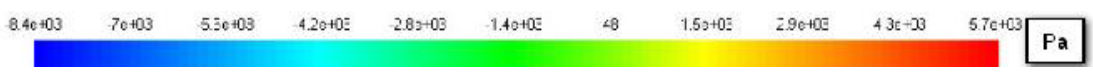

Fig. 5. Static pressure contour around CRH380A body (a)V=100km/h (b)V=190 km/h (c) V=220 $\mathrm{km} / \mathrm{h}(\mathrm{d}) \mathrm{V} 350 \mathrm{~km} / \mathrm{h}$.

Figure 6 shows the velocity vector around the back-end of the train at the speed of 100 $\mathrm{km} / \mathrm{h}, 190 \mathrm{~km} / \mathrm{h}, 220 \mathrm{~km} / \mathrm{h}$ and $350 \mathrm{~km} / \mathrm{h}$. Vortex occurs at the speed of $100 \mathrm{~km} / \mathrm{h}$ and 190 $\mathrm{km} / \mathrm{h}$, while it disappear at the speed of $220 \mathrm{~km} / \mathrm{h}$ and $350 \mathrm{~km} / \mathrm{h}$. The disappearance of 
vortex at higher train speed is affected by the domination of the inertial forces following the high speed of flow around the train body. Large inertial forces drive the fluids flow sequentially on the geometry of the body profile of the train.

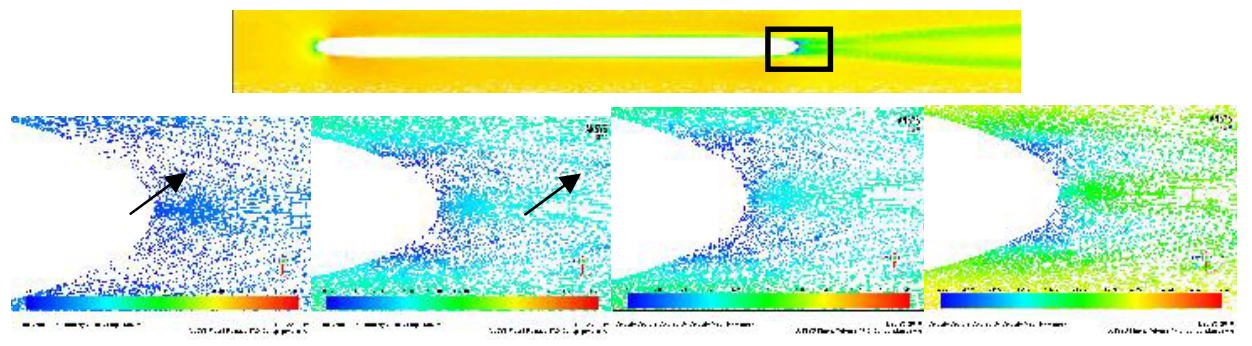

(a)

(b)

(c)

(d)

Fig. 6. Velocity vector around the end of train body on a plane of $0.8 \mathrm{~m}$ high from the ground at various speed (a) V=100 km/h (b) V=190 km/h (c) V=220 km/h (d) V=350 km/h.

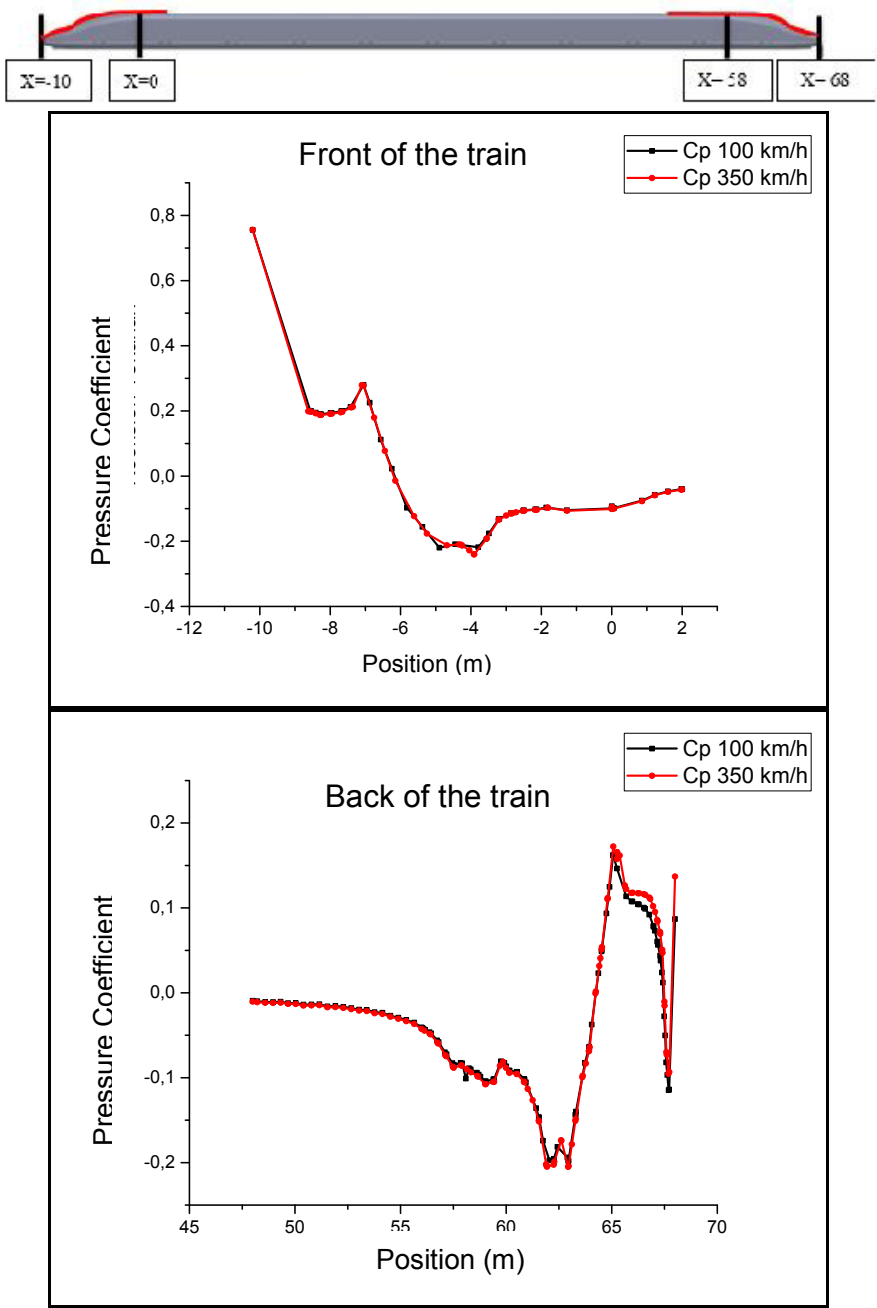

Fig. 7. Pressure coefficient on train geometries profile at traveling speed of $100 \mathrm{~km} / \mathrm{h}$ and $350 \mathrm{~km} / \mathrm{h}$. 
Figure 7 shows pressure coefficient on the front and back of the train at speed of 100 $\mathrm{km} / \mathrm{h}$ and $350 \mathrm{~km} / \mathrm{h}$. It can be observed that the pressure coefficient on the front of the train at the speed of $100 \mathrm{~km} / \mathrm{h}$ is almost the same with that of $350 \mathrm{~km} / \mathrm{h}$. The highest pressure coefficient is at stagnation point on the front of the train. The pressure coefficient then decrease and at some point increase again caused by the blunt geometries between train and glass body wheelhouse. After passing through the glass rudder, the pressure coefficient tends to have a lower than that at the nose of the train. While at the back of the train, there is different pressure coefficient profile between $100 \mathrm{~km} / \mathrm{h}$ and $350 \mathrm{~km} / \mathrm{h}$ of train speed. At the speed of $100 \mathrm{~km} / \mathrm{h}$, the pressure coefficient on the back of the train body is lower than the pressure coefficient at the train speed of $350 \mathrm{~km} / \mathrm{h}$. The low pressure in the rear of the train makes a large pressure difference between the front and rear of the train, hence the pressure drag coefficient is higher. Therefore, at higher speeds, the pressure drag coefficient is lower than the that at lower speeds.

\section{Conclusion}

The aerodynamic characteristics of Jakarta-Bandung high speed train has been analyzed using CFD. The results show that the drag force is increase proportionally with the train speed. On the other side, the drag coefficient $\left(C_{\mathrm{D}}\right)$ is slightly decrease by the increase of train speed. A negative lift force occurs at all speed, means the high speed train is experiencing a down force in all travelling speed from $100 \mathrm{~km} / \mathrm{h}$ to $350 \mathrm{~km} / \mathrm{h}$. This negative lift force or the down force can be referred that the high speed train travel in safety and the risk of lifted out accident caused by the aerodynamic forces can be reduced or eliminated.

The total drag coefficient consists of pressure drag coefficient and viscous drag coefficient. In the case of a high speed train, the influence of viscous drag coefficient is more dominant than pressure drag coefficient due to the configuration of a very long body of the train compare to its height or width. Both coefficients are decrease versa the increase of speed.

The high pressure area is located at the nose of the train. The pressure acting on this location is increase proportionally to the train speed. At its maximum speed, the pressure drag is high and so is the drag force acting on the train.

At a lower traveling speed, the pressure coefficient on the back of the train body is lower that at a higher traveling speed. The low pressure in the rear of the train makes a large pressure difference between the front and rear of the train, hence the pressure drag coefficient is higher. Therefore, at higher speeds, the pressure drag coefficient is lower than the that at lower speeds.

\section{References}

1. C. Baker, J. Wind. Eng. Aerodyn., 98, 277-298 (2010)

2. R.S. Raghunatan, H. D. Kim, T. Setoguchi, Prog. in Aerospace Sciences, 38, 469-514 (2002)

3. M. Suzuki, K. Tanemoto, T. Maeda, J. Wind. Eng. Aerodyn., 91, 209-218 (2003)

4. Y. Shuanbao, G. Dilong, S. Zhenxu, Y. Guowei, C. Dawei, Comp. and Fluids, 95, 5673 (2014)

5. J. Paniagua, M. Garcia, A. Crespo, J. Wind. Eng. Aerodyn., 130, 48-61(2014) 